\title{
Giant Burrowing Mayfly (suggested common name) Hexagenia limbata (Serville 1829) (Insecta: Ephemeroptera: Ephemeroidea: Ephemeridae) ${ }^{1}$
}

\author{
Alexander B. Orfinger and Andrea Lucky²
}

\section{Introduction}

The giant burrowing mayfly, Hexagenia limbata (Serville, 1829) (Figure 1) is one of the most widespread mayflies in North America and is well known for its importance in ecosystem health and water quality monitoring. The mayflies (order Ephemeroptera) are an ancient lineage of aquatic insects originating more than 300 million years ago (Merritt and Cummins 2008). Within this order, the burrowing mayflies of the family Ephemeridae are wellknown for their importance in fly fishing and their massive synchronized mating flights.

\section{Synonymy}

As demonstrated by the large number of synonymous names below, Hexagenia limbata has inadvertently been described numerous times due to its variable appearance and wide geographic distribution.

\section{Synonyms:}

Ephemera limbata Serville (1829)

Hexagenia affiliata McDunnough (1927)

Hexagenia californica Upholt (1937)

Hexagenia carolina Traver (1931)

Hexagenia elegans Traver (1931)

Hexagenia kanuga Traver (1937)

Hexagenia marilandica Traver (1931)

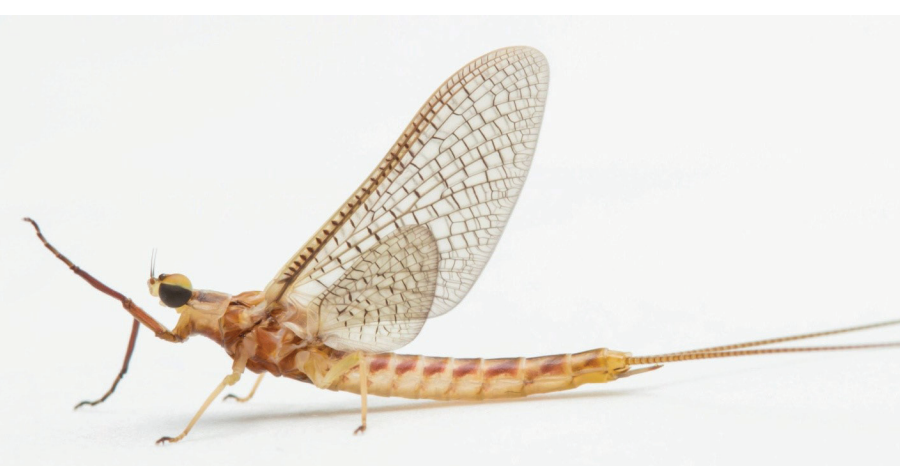

Figure 1. Female adult (imago) Hexagenia limbata (Serville) in Winnipeg, Manitoba, Canada. Credits: Miles Zhang, UF/IFAS

Hexagenia mingo Traver (1931)

Hexagenia munda Eaton (1883)

Hexagenia occulta Walker (1853)

Hexagenia pallens Traver (1935)

Hexagenia rosacea Traver (1931)

Hexagenia variabilis Eaton (1883)

Hexagenia venusta Eaton (1883)

Hexagenia viridescens Walker (1853)

Hexagenia weewa Traver (1931)

Palingenia limbata Serville (1829)

Palingenia occulta Walker (1853)

Palingenia viridescens Walker (1853)

1. This document is EENY-726, one of a series of the Entomology and Nematology Department, UF/IFAS Extension. Original publication date April 2019. Visit the EDIS website at https://edis.ifas.ufl.edu for the currently supported version of this publication.

2. Alexander B. Orfinger, Florida A \& M University; and Andrea Lucky, assistant professor, Entomology and Nematology Department; UF/IFAS Extension, Gainesville, FL 32611.

The Institute of Food and Agricultural Sciences (IFAS) is an Equal Opportunity Institution authorized to provide research, educational information and other services only to individuals and institutions that function with non-discrimination with respect to race, creed, color, religion, age, disability, sex, sexual orientation, marital status, national origin, political opinions or affiliations. For more information on obtaining other UF/IFAS Extension publications, contact your county's UF/IFAS Extension office. 


\section{Distribution}

The giant burrowing mayfly is widespread throughout North America. While the species reaches its greatest densities in the Great Lakes region, it is known to occur in most of Canada and all US states and the District of Columbia, with the exception of Alaska, Hawaii, New Mexico, and Arizona (Randolph 2002; McCafferty and Jacobus 2007) (Figure 2). The species' range extends south into the Mexican states of Jalisco, Nuevo Leon, San Luis Potosi, and Tabasco (Randolph 2002; McCafferty and Jacobus 2018). Throughout its range, Hexagenia limbata inhabits lakes and slower reaches of streams, which have sandy or muddy substrate.

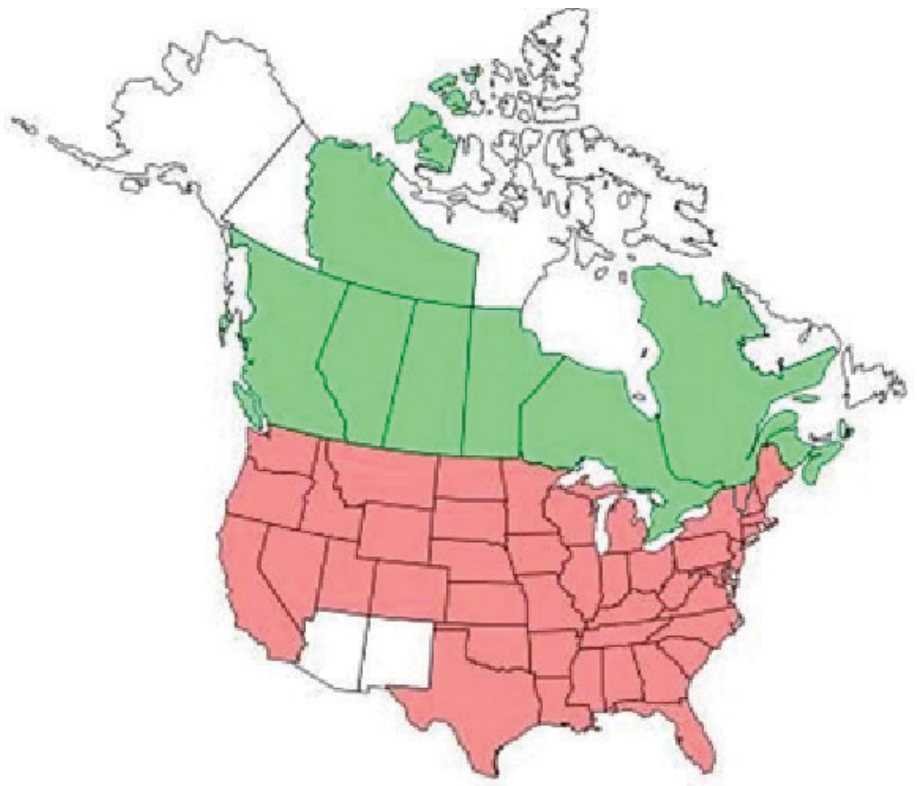

Legend: Present in USA State CAN Province

Figure 2. Distribution of Hexagenia limbata (Serville) in North America north of Mexico. Map generated and updated based on available scientific literature.

Credits: Modified from original version which was sourced with permission from www.flyfishingentomology.com

\section{Description}

\section{Egg}

The oval egg is roughly textured and measures 0.16 to 0.19 by 0.28 to 0.32 millimeters (Hunt 1951). Eggs are laid in batches and healthy, fertilized eggs are cream colored whereas nonviable eggs appear dark in color (Giberson and Rosenberg 1992).

\section{Nymph}

The nymph of Hexagenia limbata has a long, cylindrical body form that is characteristic of ephemerid mayflies (Morse et al. 2017) (Figure 3). Late instar nymphs grow to body lengths of $2.5 \mathrm{~cm}$ (males) to $3.0 \mathrm{~cm}$ (females), have dark wing pads, and three cerci (appendages at the posterior end of the abdomen) (Morse et al. 2017). Filamentous gills arise from the sides of the abdomen and orient dorsally, appearing to lay on the insect's dorsal side (Morse et al. 2017). These gills are conspicuous and are larger than those of other ephemerid mayflies (Hynes 1970). The mandibles curve upward and are tusk-like (Morse et al. 2017). The body color is variable but is generally yellow or light brown.

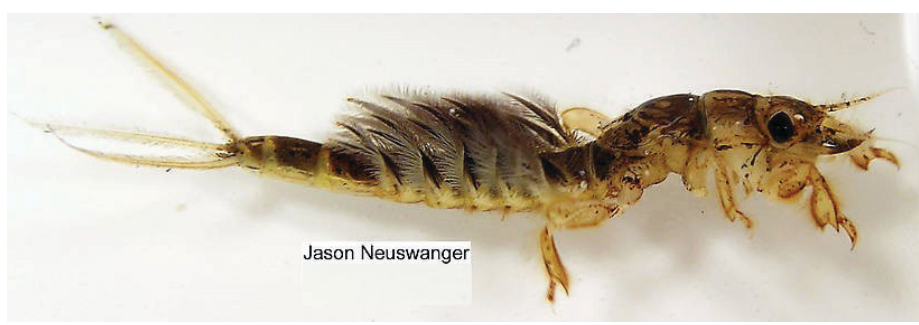

Figure 3. Late instar nymph of Hexagenia limbata (Serville) from Wisconsin, US. Note the feathery gills that fold dorsally and the tusklike mandibles.

Credits: Jason Neuswanger

\section{Subimago}

Subimago is the term given to subadult mayflies that have emerged from the water and have wings but are not yet reproductive. This penultimate life stage is unique among extant insect orders. In all species including Hexagenia limbata, the subimago superficially resembles the adult but can be distinguished by a few differences. Subimagoes are duller in color than imagoes and their wings and bodies are covered in minute hairs called microtrichia (Merritt and Cummins 2008). These hairs make the wings appear opaque and are the most distinctive feature of a subimago. This can be contrasted with the clear wings of the true adult, or imago (Merritt and Cummins 2008). Subimagoes tend to have shorter legs and cerci than reproductive adults (Merritt and Cummins 2008).

\section{Imago}

The imago is the winged, reproductive adult mayfly. Adult Hexagenia limbata are large mayflies attaining a body length of up to $3 \mathrm{~cm}$, excluding the two cerci that themselves reach about $3 \mathrm{~cm}$. The adult color is variable but is generally a shade of brown or yellow (McCafferty 1975). Hexagenia limbata has a large pair of clear forewings and a smaller pair of hindwings with a dark border. Wings are held pressed together above the body when at rest (Edmunds et al. 1976). Unlike the nymphs, adults of Hexagenia limbata have only two cerci. Sexual differences include the males' longer cerci and forelegs; however, males tend to be smaller than females and have larger eyes (Figure 4). 


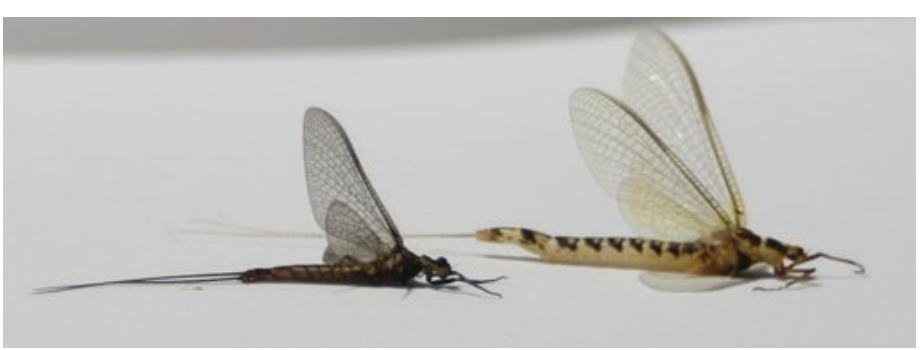

Figure 4. Male (left) and female (right) adults of Hexagenia limbata (Serville).

Credits: John Simonson, wiflyfisher.com

\section{Life History}

One adult female can produce up to 8,000 eggs, with an average of about 4,000 (Hunt 1951). Eggs of Hexagenia limbata are laid on the water surface and sink to the sandy substrate. At southern latitudes, oviposition can occur year-round whereas in colder climates eggs are generally laid in the fall. The submersed eggs overwinter and nymphs hatch in the spring.

Neonate naiads (newly hatched nymphs) are about $1 \mathrm{~mm}$ in length. Immediately after hatching, naiads of this species burrow in sandy sediments of flowing freshwater, where they construct U-shaped tunnels with two openings to the water. The naiads undulate their bodies and wave their gills to pull water through the tunnel. By cycling water across their bodies, the naiads are able to filter out and feed on organic material suspended in the water and extract oxygen from the fresh water as it passes over their gills. Hexagenia limbata spends most of its life in the aquatic stages, living from four months to two years as naiads, depending on the latitude (McCafferty and Jacobus 2007). During this time, the naiads undergo up to 30 molts.

Adults emerge year-round in warmer climates and in the summer or fall in cooler climates. When ready to emerge as subimagoes, nymphs swim to the water surface and simultaneously break through the larval skin and emerge as a subimago (Fremling 1967). They quickly fly to the cover of the shoreline vegetation, where they molt to the imago stage the following day, after which mating occurs (Fremling 1967). These emergences tend to occur en masse. At sunset, large groups of freshly eclosed adults meet aerially and mate while in flight. Males fly through aggregations of airborne females and clasp on to an individual female using their long forelegs. After copulation, which lasts a few seconds and occurs once in flight, females deposit batches of fertilized eggs into the water. The entire lifespan of adults is no more than two days, during which time they are unable to feed with their vestigial mouth parts. Hexagenia limbata exhibits a univoltine lifecycle, meaning that only one brood of eggs is produced annually (Edmunds et al. 1976; Lobinske et al. 1996).

\section{Importance}

Hexagenia limbata is a major contributor to ecosystem function, water quality monitoring, and the fly-fishing community. In its range, where it often occurs at high densities, the species constitutes a substantial proportion of aquatic biomass (Lobinske et al. 1996). In all life stages, Hexagenia limbata is a significant prey item for many fish species and other invertebrates. Hexagenia limbata is important for nutrient cycling as it removes significant biomass from the freshwater systems it inhabits when it emerges en masse. Much of that biomass is then reintroduced to the terrestrial environment.

Hexagenia limbata has been known to cause problems for people as a result of the large numbers of individuals that are involved in its synchronized emergences. In the northern half of their range where they are more abundant, this species can be detected on weather radar during the adult flights and is sometimes confused with storm activity (Figure 5). During flights and after they die, swarms can result in dangerous road conditions (car collisions have resulted), road closures, and a far-reaching smell of meter-deep decaying insect piles. Snow plows often have to be used to clear the piles of dead Hexagenia mayflies from roads.

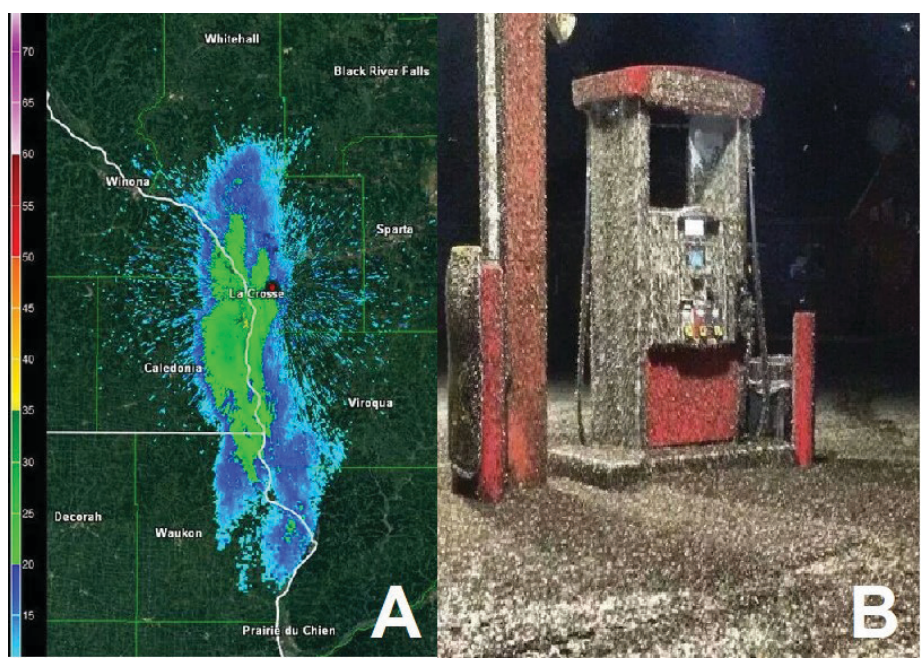

Figure 5. A) A weather radar image of Hexagenia limbata hatch along the Mississippi River in 2014. B) A typical scene from the same 2014 hatch as massive adult numbers are attracted to lights near waterways.

Credits: National Weather Service 
Despite being an occasional nuisance, Hexagenia limbata is useful for monitoring water quality (e.g., Fremling 1964).

Mayflies in general, including Hexagenia limbata, are intolerant of poor (e.g., polluted) water quality. The species' presence indicates a healthy body of water, and the nymphs are routinely sampled by government and private agencies to monitor water conditions. Mayflies are of great importance to the fly-fishing community, with Hexagenia limbata perhaps representing the most relevant species (McCafferty 1983). People who fly fish often have a keen understanding of the biology of Hexagenia limbata, optimally using flies to exploit maximum emergence times and mimic Hexagenia limbata landing behavior as the fly hits the water (McCafferty 1983). Fly fishers have even developed their own terminology for the group, referring to subimagoes as duns and adults as spinners. Fishing flies that closely mimic mayfly adults, subimagoes and naiads are produced commercially and sold in the Great Lakes region for both fly and reel fishing (Figure 6).

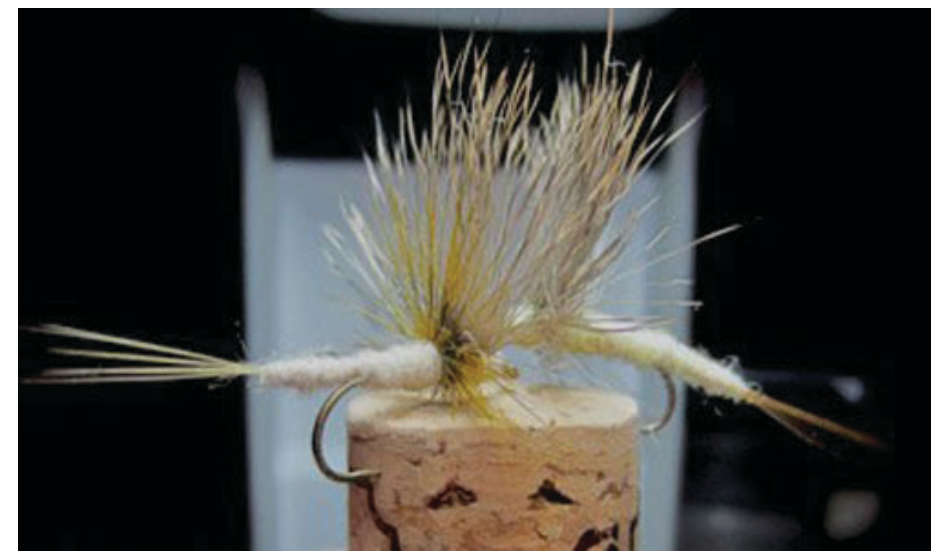

Figure 6. Fly fishing flies tied to mimic Hexagenia limbata (Serville). Credits: John Simonson, wiflyfisher.com

\section{Selected References}

Edmunds Jr GF, Jensen SL, Berner L. 1976. The Mayflies of North and Central America. Minneapolis, MN: University of Minnesota Press.

Fremling CR. 1964. "Mayfly distribution indicates water quality on the Upper Mississippi River." Science 146: 1164-1166.

Fremling CR. 1967. "Methods for mass-rearing Hexagenia mayflies (Ephemeroptera: Ephemeridae)." Transactions of the American Fisheries Society 96: 407-410.

Giberson DJ, Rosenberg DM. 1992. "Effects of temperature, food quantity, and nymphal rearing density on life-history traits of a northern population of Hexagenia
(Ephemeroptera: Ephemeridae)." Journal of the North American Benthological Society 11: 181-193.

Hunt BP. 1951. "Reproduction of the burrowing mayfly, Hexagenia limbata (Serville), in Michigan." Florida Entomologist 34: 59-70.

Hynes HBN. 1970. The Ecology of Running Waters. Toronto, Canada: University of Toronto Press.

Lobinske RJ, Ali A, Stout IJ. 1996. "Life history and productivity of Hexagenia limbata (Ephemeroptera: Ephemeridae) and selected physico-chemical parameters in two tributaries of the Wekiva River, Central Florida." Florida Entomologist 79: 543-551.

McCafferty WP. 1975. "The burrowing mayflies of the United States (Ephemeroptera: Ephemeroidea)." Transactions of the American Entomological Society 101: 447-504.

McCafferty WP. 1983. Aquatic Entomology: The Fishermen's and Ecologists' Illustrated Guide to Insects and their Relatives. Boston, MA: Jones \& Bartlett Learning.

McCafferty WP, Jacobus LM. 2007. Mayfly Central: Mayflies of North America. Electronic database accessible at http://www.entm.purdue.edu/entomology/research/mayfly/ mayfly.html. Purdue University, West Lafayette, Indiana, USA. Accessed 18 September 2018.

Merritt RW, Cummins KW. 2008. An Introduction to the Aquatic Insects of North America. 4th Edition. Dubuque, IA: Kendall Hunt.

Morse JC, McCafferty WP, Stark BP, Jacobus LM. 2017. Larvae of the Southeastern USA Mayfly, Stonefly, and Caddisfly Species:(Ephemeroptera, Plecoptera, and Trichoptera). Clemson Public Service and Agriculture. Clemson, SC: Clemson University.

Randolph RP. 2002. Atlas and Biogeographic Review of North American Mayflies (Ephemeroptera). West Lafayette, IN: Doctoral dissertation. Purdue University.

Serville JG. 1829. Description of Ephemera limbata. GuerinMeneville, FE Jconographie du Regne animal de G. Cuvier France, 2 pp. 